\title{
Effect of Estradiol-17, $\beta$ on the Magnitude and Distribution of Uterine Blood Flow in Nonpregnant, Oophorectomized Ewes
}

\author{
Gharles R. Rosenfeld, Allen P. Killam, Frederick C. Battaglia ${ }^{[21]}$, \\ Edgar L. Makowski, and Giacomo Meschia \\ Division of Perinatal Medicine, Departments of Obstetrics-Gynecology, Pediatrics, and Physiology, \\ University of Colorado Medical Center, Denver, Colorado, USA
}

\begin{abstract}
Extract
In seven nonpregnant sheep studied either acutely or chronically there was an increase in total uterine blood flow after the systemic, 2-min infusion of $1.0 \mu \mathrm{g} / \mathrm{kg}$ of estradiol-17, $\beta$. The mean control flow was $20 \pm 3 \mathrm{ml} / \mathrm{min}$ and the mean flow, measured approximately $2 \mathrm{hr}$ after estradiol, was $283 \pm 50 \mathrm{ml} / \mathrm{min}(P<0.001)$. The chronic preparations showed a mean increase in flow that was $186 \mathrm{ml} / \mathrm{min}$ greater than that measured in the acute preparations. The blood flow to all uterine tissues increased markedly after the injection of estrogen, and the distribution of flows within the uterus was not altered.

The correlation coefficient between total arterial flow to the uterus, measured by the microsphere method, and the sum of blood flows in the left and right uterine arteries, measured with electromagnetic flow probes, was 0.987 .

The blood flow to the mammary gland and vagina also increased after the administration of estradiol.

\section{Speculation}

This study demonstrates that the vasculature of all of the tissues of the nonpregnant ovine uterus, endometrium, myometrium, and caruncles is extremely sensitive to the vasodilatory effects of estradiol-17, $\beta$. Inasmuch as the arterioles supplying blood to the caruncles are the same as those that perfuse the placental cotyledons in the pregnant state, these data support the hypothesis that estrogens play an important role in the regulation of placental blood flow.
\end{abstract}

\section{Introduction}

There is little information about the factors that regulate placental blood flow. Because the placenta is the respiratory organ of the fetus it has been suggested that the respiratory gases play an important role in this regulation, on the assumption that the blood flow to a respiratory organ is controlled by the pressures of
$\mathrm{O}_{2}$ and $\mathrm{CO}_{2}$. However, acute changes of $\mathrm{O}_{2}$ tension do not have significant direct effect on placental perfusion $[2,14]$. There is some evidence $[3,4,6,7]$ that uterine blood flow is hormonally regulated both in the nonpregnant and pregnant state. The uterine blood flow in late pregnancy is primarily placental flow [9], which suggests that placental blood flow may also be hormonally regulated. 
In sheep, those areas of the uterine mucosa that are used for the formation of placental cotyledons are separate anatomical entities, clearly visible on the internal surface of the nonpregnant uterus in the form of approximately 100 round structures (caruncles) spaced in rows. Hence, this species presents the opportunity of measuring in the nonpregnant state the effect of hormones on that portion of the uterine vasculature which supplies blood to the placenta during gestation.

\section{Materials and Methods}

\section{Biologic Preparation}

The preparation consisted of nonpregnant, oophorectomized ewes with electromagnetic flow probes implanted around both uterine arteries. Catheters were placed in the following locations: ( 1 ) both femoral arteries, (2) the inferior vena cava, and (3) the left ventricle (Fig. 1).

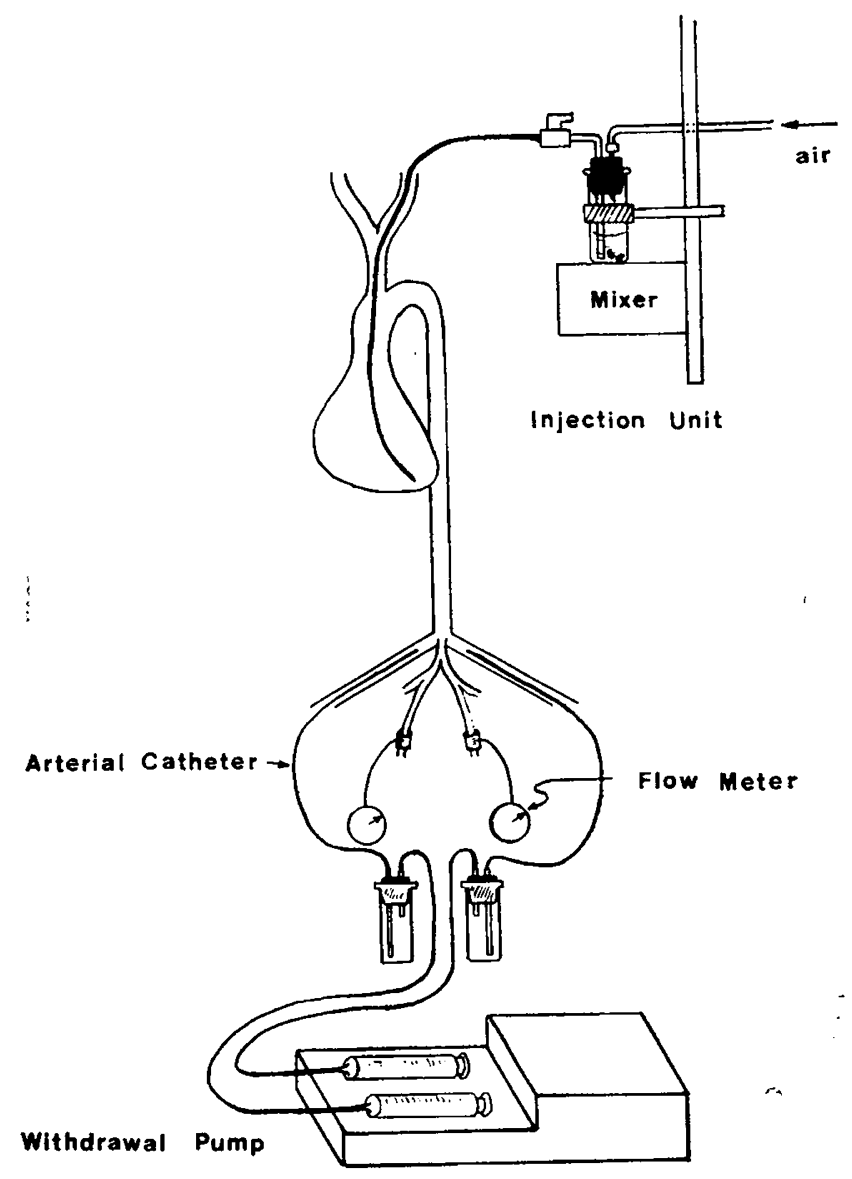

Fig. 1. Scheme of the biologic preparation.
In four sheep all catheters and flow probes were placed as one surgical procedure. The animals were then maintained in restraining pens, and the uterine blood flows were measured daily by means of flowmeters before and after intravenous injection of estradiol-17, $\beta(1 \mu \mathrm{g} / \mathrm{kg})$. When the animals appeared fully recovered from surgery, radioactive microspheres were injected via the left ventricular catheter before and after estrogen stimulation. Venous and arterial pressures and pulse rate were monitored continously throughout each experiment.

In a second "stressed" group of three animals, the placement of the left ventricular catheter was delayed until the day of the microsphere injection. In this group, the microspheres were infused while the anesthetized animals were restrained on the operating table.

\section{Surgical Procedures}

Left ventricular catheter. The animals were fasted for $48 \mathrm{hr}$ prior to surgery. They were sedated with intravenous pentobarbital $(5 \mathrm{mg} / \mathrm{kg})$, and $1 \%$ xylocaine was used for local anesthesia. The left carotid artery was located and ligated distally. A radiopaque catheter [15] (1.2 $\mathrm{mm}$ i.d. by $2.2 \mathrm{~mm}$ o.d.) was inserted into the carotid artery and passed into the left ventricle (LV) under fluoroscopy. The free end was sutured to the skin. The catheter was filled with heparinized saline $(1000 \mathrm{U} / \mathrm{ml})$, clamped, and placed in an external pouch attached to the neck.

Abdominal surgery. The sheep were given spinal anesthesia (6 $\mathrm{mg}$ tetracaine hydrochloride) supplemented with intravenous pentobarbital as required. Through a midline incision the nonpregnant uterus was identified and delivered onto the abdomen. Bilateral oophorectomy was performed and electromagnetic flow probes [16] (3.0-3.5 mm i.d.) were placed around the right and left uterine arteries as described by Killam et al. [7]. Polyvinyl catheters $(0.9 \mathrm{~mm}$ i.d. by 1.2 $\mathrm{mm}$ o.d.) were passed into both femoral arteries to a level just below the trifurcation of the abdominal aorta. Another catheter of the same size was placed in the inferior vena cava to the level of the diaphragm via a femoral vein. All catheters and flow probes were carried out to the flank through a subcutaneous tunnel and placed into an external pouch [7]. The catheters were flushed daily with heparinized saline (1000 U/ $\mathrm{ml})$. Penicillin $(600,000 \mathrm{U})$ and streptomycin $(0.5 \mathrm{~g})$ were given on the day of surgery and on the subsequent 3 days. 


\section{Microsphere Infusion}

Radioactive carbonized microspheres [17] with a specific activity of $10 \mathrm{mCi} / \mathrm{g}$ and a mean diameter of 25 $\mu \mathrm{m} \pm 5$ sD were employed. Approximately $150 \mu \mathrm{Ci}$ ${ }^{141} \mathrm{Ce}$ and $350-400 \mu \mathrm{Ci}{ }^{51} \mathrm{Cr}$ were administered to each animal. The exact amount infused was determined as follows. The microspheres were added to separate preweighed counting vials containing magnetic stirring rods. Sterile saline $(8-10 \mathrm{ml})$ and Tween-20 (l drop) were added to each vial and the vials were reweighed. A magnetic stirrer was used to mix the suspensions for $45 \mathrm{~min}$. Four $0.10-\mathrm{ml}$ samples were removed from each of the microsphere suspensions in lengths of preweighed polyethylene catheter while mixing was continued. The catheters plus suspensions were placed into separate preweighed counting vials, weighed, and each counted in duplicate. From these data the mean

Table $I$. The total number of microspheres and total counts per minute of radioactivity infused into the seven animals reported in this paper and nine other animals whose uterine blood flows were used to correlate the microsphere and flow probe data

\begin{tabular}{ccr} 
& No. of microspheres infused & Infusion, cpm \\
\hline${ }^{141} \mathrm{Ce}$ & & \\
Mean & 837,568 & $11,811,746$ \\
$\pm \mathrm{SD}$ & 187,433 & $6,895,236$ \\
$\pm \mathrm{SEM}$ & 50,094 & $1,842,829$ \\
${ }^{51} \mathrm{Cr}$ & & \\
$\mathrm{Mean}$ & $1,972,412$ & $13,222,713$ \\
土SD & 810,001 & $7,089,994$ \\
土SEM & 224,654 & $1,966,411$ \\
\hline
\end{tabular}

counts per gram of solution were calculated. The unit for infusing the microspheres is shown in Figure 1. It consisted of a rubber stopper which tightly sealed the vial containing the suspension of microspheres, a piece of right-angle glass tubing which passed through the stopper and connected to a three-way stopcock, and a 14-gauge metal needle inserted through the stopper. After the entire unit had been weighed, it was placed on a magnetic stirrer-heater unit [18] and connected to the LV catheter as illustrated in Figure 1. At the time of infusion, air was forced through the 14-gauge needle at a constant rate with a 50-cc syringe. The suspension was infused over $30-40 \mathrm{sec}$ while mixing; then the LV catheter was flushed with $10 \mathrm{ml}$ isotonic saline. After infusion of the microspheres the entire administration unit was reweighed, and the total counts per minute and number of microspheres infused were determined (Table I).

Starting a few seconds before the microsphere infusion, reference samples were withdrawn directly into counting vials by a Harvard pump from both femoral artery catheters at a rate of $3.99 \mathrm{ml} / \mathrm{min}$ for $3 \mathrm{~min}$, as previously described [10]. This procedure was performed with ${ }^{141} \mathrm{Ce}$ prior to the administration of estradiol-17, $\beta$, and with ${ }^{51} \mathrm{Cr}$ at the time of maximum uterine blood flow as recorded by the flow probes (Fig. 2).

\section{Tissue Preparation}

The ewes were killed within $24 \mathrm{hr}$ after the second microsphere infusion and dissected for tissue preparation. The uterus, vagina, and cervix were removed en bloc. The vaginal tissue was removed, and then the

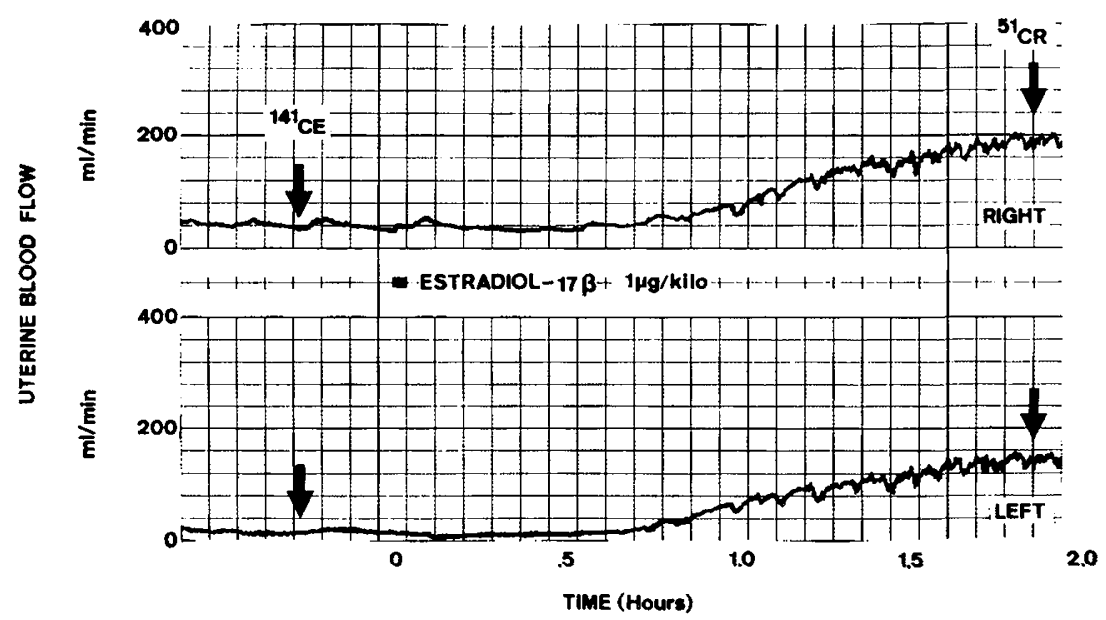

Fig. 2. A continuous recording of uterine flow with the flowmeters, indicating the time of microsphere injection and of the 2-min estradiol infusion. Time zero marks the beginning of the estrogen infusion. 

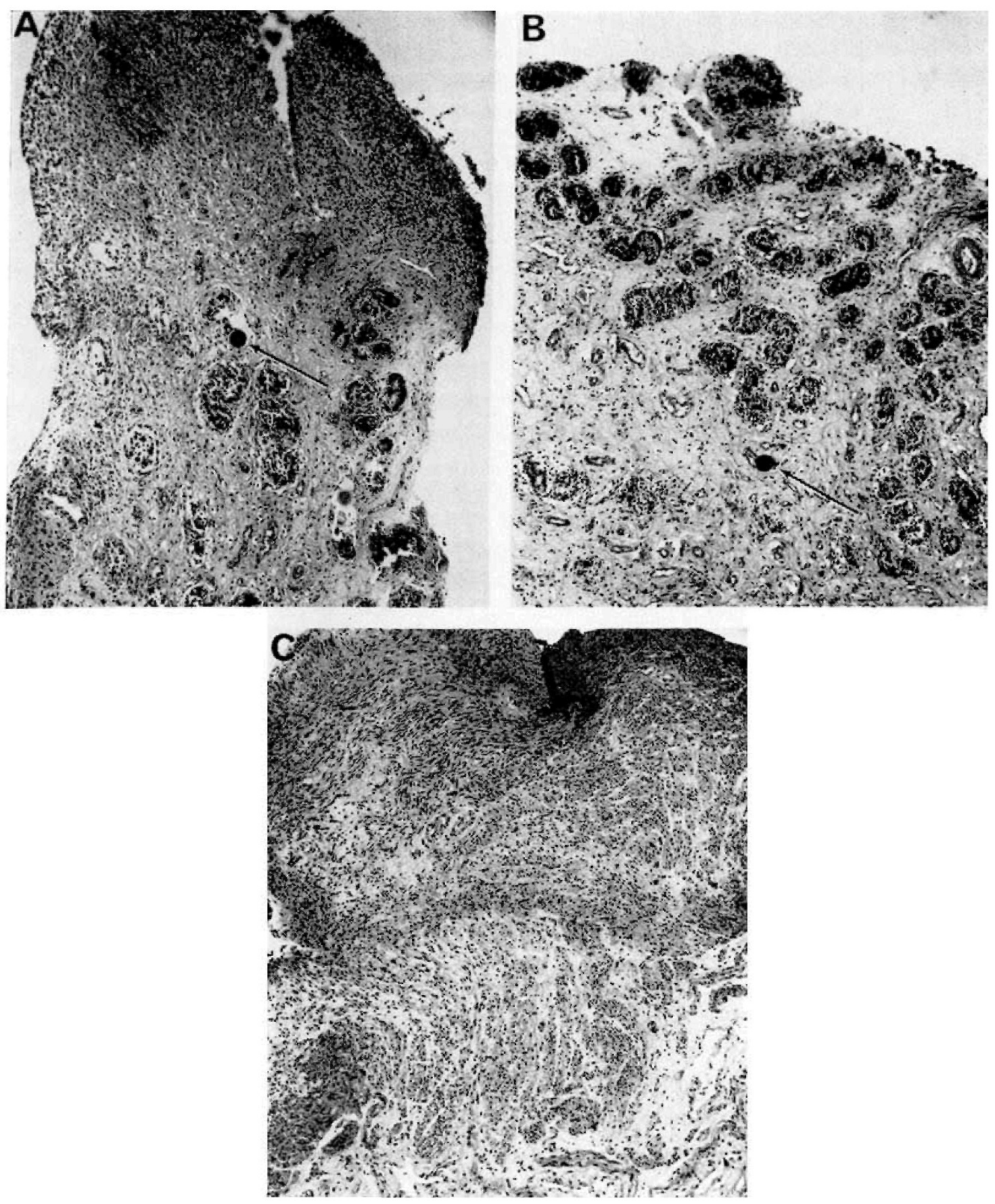

Fig. 3. Histology of the three uterine tissues analyzed separately in this study. $\times 50$. Arrows indicate trapped microspheres in precapillary arterioles in the caruncle $(A)$ and endometrium $(B)$. The myometrium is shown in $C$.

cervix and uterus were opened and the cervix was removed at its junction with the uterine corpus. The caruncles from each horn were removed individually. The endometrium and myometrium were separated by blunt and sharp dissection. This separation was confirmed histologically (Fig. 3). All tissue was placed in preweighed, numbered counting vials $(25 \mathrm{~mm}$ diameter by $80 \mathrm{~mm}$ length). The mammary gland was re- 
moved and homogenized and aliquots placed in the preweighed vials.

\section{Radioactive Assay}

The samples were counted in an automatic dualchannel gamma counter [19] with a 3-inch crystal detector and a wide well $\left(11 / 8\right.$ inch diameter). The ${ }^{51} \mathrm{Cr}$ was counted at an emission peak of $0.321 \mathrm{meV}$ (window range $0.271-0.371 \mathrm{meV})$. The ${ }^{141} \mathrm{Ce}$ was counted at a peak of $0.145 \mathrm{meV}$ (window range $0.127-0.162 \mathrm{meV}$ ). Under these conditions, $4.5-5.5 \%$ of the ${ }^{51} \mathrm{Cr}$ counts appeared in the ${ }^{141} \mathrm{Ce}$ window, and $0.3-0.7 \%$ of the ${ }^{141} \mathrm{Ce}$ counts appeared in the ${ }^{51} \mathrm{Cr}$ window. The true counts per minute for each isotope were calculated by solution of the appropriate simultaneous equations.

During the course of this study the accuracy of measuring gamma radiation in tissue samples was investigated. The effect of height of samples within vials was studied by placing a solution containing free isotope into a counting vial and determining the counts per minute at various meniscus heights, starting at 0.20 $\mathrm{cm}$, increasing by $0.20-\mathrm{cm}$ increments to $1.0 \mathrm{~cm}$ and then by $1.0-\mathrm{cm}$ increments to $4.0 \mathrm{~cm}$. Table II presents the results. Because of these results, tissue samples were kept within $1.0 \mathrm{~cm}$ height in the vials. The effect upon counting efficiency of the method of tissue preparation was also studied. Whole tissue slices and tissues which were prepared by either grinding or homogenization were counted, then ashed in a muffler oven at $350^{\circ}$ for $45 \mathrm{~min}$, desiccated at $100^{\circ}$ for $24 \mathrm{hr}$, or digested in concentrated $\mathrm{HCl}$ and recounted. The arterial reference samples were counted with the tissues initially and again after the above procedures had been performed, so as to obtain a ratio between the two sets of counts that would take into account the normal decay of the isotopes. This ratio was used as a reference for the tissue samples. We were unable to demonstrate any effect upon counts per minute obtained by performing any of the above procedures on tissues from lung, brain, liver, or uterus. Thus, desiccation, digestion, and ashing appeared to be unnecessary in the preparation of "soft" tissues for counting.

Flows to the uterine tissues were determined from the total counts obtained for each tissue, whereas flows to the mammary gland and vagina were determined from the mean counts per minute per gram of tissue. All vials were counted for 40 min or 40,000 counts.

\section{Data Reduction}

Individual organ blood flows were calculated using the integrated arterial reference samples in the manner
Table II. The effect of sample height within the counting vial on the efficiency of gamma counting ${ }^{1}$

\begin{tabular}{cc}
\hline Height, cm & Decrease in total counts per minute, \% \\
\hline 0.5 & -1.94 \\
1.0 & -4.20 \\
2.0 & -11.63 \\
3.0 & -15.89 \\
4.0 & -23.26 \\
\hline
\end{tabular}

${ }^{1}$ Percentage decrease in counts per minute (counts per minute at $0.2 \mathrm{~cm}$ height $=$ reference counts per minute) with increasing meniscus height.

described by Makowski et al. [10]:

$$
\begin{aligned}
& \text { Organ blood flow }(\mathrm{ml} / \mathrm{min}) \\
& =\frac{\text { total } \mathrm{cpm} \text { for an organ }}{\text { mean cpm in arterial samples }} \times \text { rate of withdrawal }
\end{aligned}
$$

The sum of the flows to the separate tissues of the uterus represented arterial blood flow to the uterus as determined by the microsphere method. This measurement was compared with the total flows in both uterine arteries recorded by the electromagnetic flow probes.

\section{Results}

\section{Reliability of the Microsphere Method}

An essential requirement of the microsphere method is the withdrawal of a reliable arterial reference sample for the calculation of flows. The variables which affect the error of the reference sample include: $(1)$ the duration of infusion and withdrawal, (2) the number of microspheres infused, and (3) the quantity of microspheres sampled. The first two of these were held relatively constant in the animals studied. Infusion was over $30-40 \mathrm{sec}$ and at a constant rate. The withdrawal time was $3 \mathrm{~min}$ in all of these studies, with a constant withdrawal rate of $3.99 \mathrm{ml} / \mathrm{min}$. The mean number of microspheres infused is presented in Table I. This number did not vary greatly from animal to animal for either ${ }^{51} \mathrm{Cr}$ - or ${ }^{141} \mathrm{Ce}$-labeled microspheres. The factor which could not be controlled was the radioactivity per microsphere. This was determined for each shipment of microspheres by placing a drop of stock microsphere solution on a cover slip, counting the number of microspheres present by light microscopy, and then determining the radioactivity per microsphere. The radioactivity per microsphere was recalculated from these cover slips before each infusion. It is apparent from the data in Table I that the total 
councs per minute infused with each isotope was quite variable.

The mean \pm SEM of the total number of microspheres withdrawn from the two arteries for ${ }^{141} \mathrm{Ce}$ and ${ }^{51} \mathrm{Cr}$ were $1024 \pm 121$ and $2735 \pm 655$, respectively. The standard error of the mean quantity of microspheres present in each reference arterial sample was estimated from paired analyses of the two arterial samples drawn simultaneously in each experiment. This error was \pm 42 microspheres for the ${ }^{141} \mathrm{Ce}$ and \pm 71 microspheres for the ${ }^{51} \mathrm{Cr}$, or $\pm 4.1 \%$ and $\pm 2.6 \%$ of the mean, respectively. Theoretically, the error should be equal to the square root of the total number of microspheres withdrawn [5]; i.e., \pm 32 microspheres in the case of the ${ }^{141} \mathrm{Ce}$ and \pm 52 for the ${ }^{51} \mathrm{Cr}$. It can be seen that the total error of estimating the quantity of microspheres in the reference samples was close to the theoretical.

\section{Comparative Flow Data}

Figure 4 shows the correlation between total arterial flow to the uterus, measured by the microsphere method, and the sum of blood flows in left and right uterine arteries, measured with electromagnetic flow probes. The points in this figure include the animals reported in this paper and eight pregnant animals involved in other studies. The mean number of microspheres given to each animal is shown in Table I. It should be noted that the two methods do not measure the same quantity, because the uterine mass used in determining the uterine flow by the microsphere method is not perfused only and exclusively via the two uterine arteries. However, the good agreement between the results of the two methods indicates that the two uterine arteries were in fact carrying most of the total uterine flow.

Effect of Estradiol on the Blood Flow to Reproductive Tissues

In all seven sheep there was an increase in total uterine blood flow following the systemic, 2-min infusion of $1 \mu \mathrm{g} / \mathrm{kg}$ estradiol-17, $\beta$. As determined by the microsphere technique, the mean control flow was 20 $\pm 3 \mathrm{ml} / \mathrm{min}$ and the mean flow measured approxi-

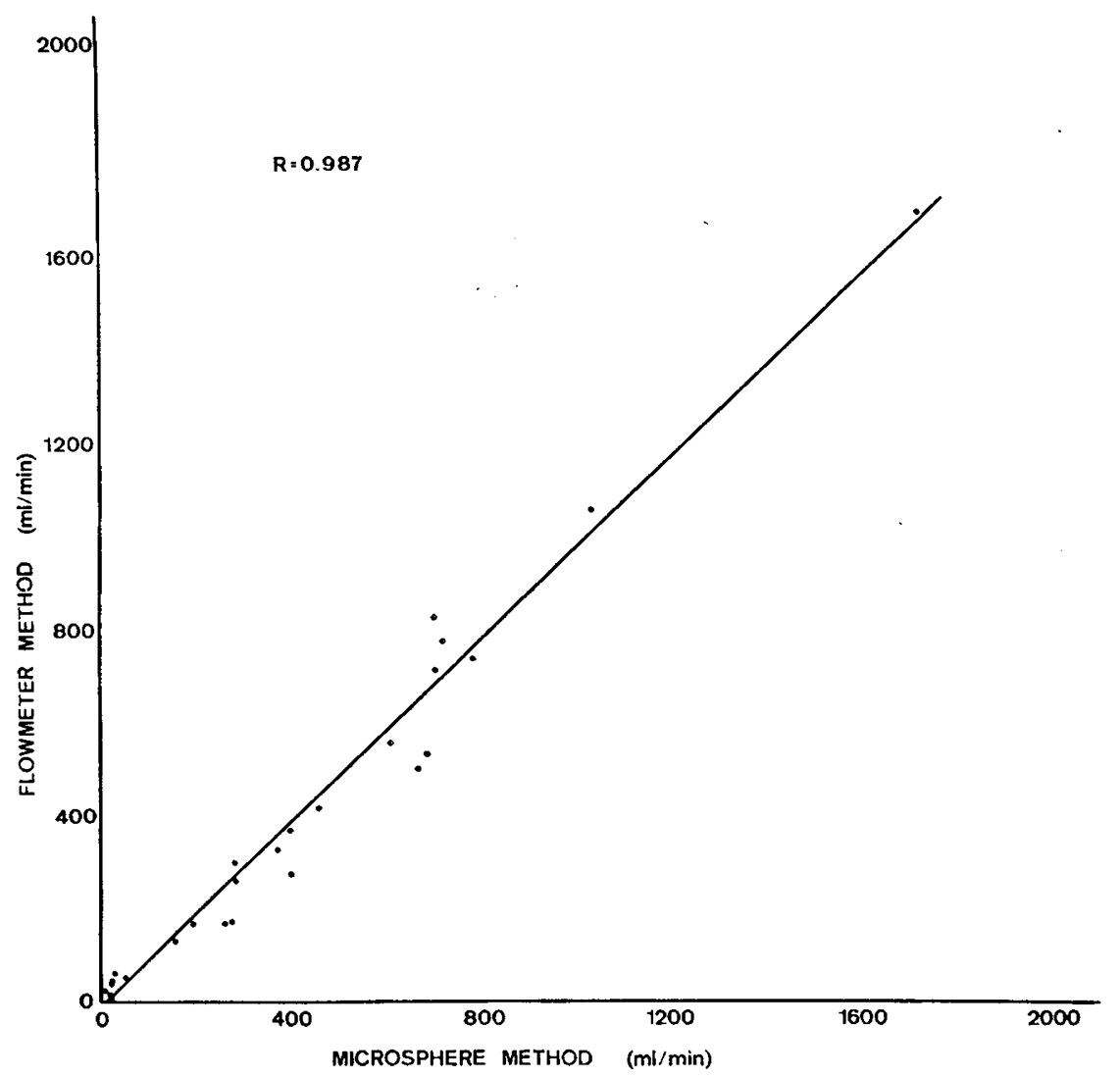

Fig. 4. Linear regression analysis of simultaneous measurements of uterine blood flow by the microsphere and electromagnetic flowmeter methods. $R=0.987$. 
Table III. The effect of estradiol-17, $\beta(1 \mu \mathrm{g} / \mathrm{kg})$ on the blood flow to the uterine tissues of seven nonpregnant ewes, as determined by the microsphere technique ${ }^{1}$

\begin{tabular}{lcc}
\hline & Before estradiol & After estradiol, $2 \mathrm{hr}$ \\
\hline $\begin{array}{l}\text { Myometrium } \\
\mathrm{ml} / \mathrm{min} \\
\mathrm{ml} / \mathrm{min} / \mathrm{g}\end{array}$ & $9.4 \pm 1.8$ & $101.9 \pm 16.2^{2}$ \\
$\quad$ Uterine flow, $\%$ & $0.16 \pm 0.03^{3}$ & $1.92 \pm 0.39^{2}$ \\
Endometrium & $39.2 \pm 2.7$ & $38.3 \pm 4.5$ \\
$\mathrm{ml} / \mathrm{min}$ & & \\
$\mathrm{ml} / \mathrm{min} / \mathrm{g}$ & $8.2 \pm 2.4$ & $95.2 \pm 19.6^{2}$ \\
$\quad$ Uterine flow, $\%$ & $0.69 \pm 0.15^{3}$ & $8.24 \pm 0.62^{2}$ \\
Caruncles & $32.3 \pm 1.9$ & $34.4 \pm 3.2$ \\
$\mathrm{ml} / \mathrm{min}$ & & \\
$\mathrm{ml} / \mathrm{min} / \mathrm{g}$ & $7.1 \pm 2.1$ & $70.4 \pm 9.4^{2}$ \\
$\quad \mathrm{Uterine}$ flow, $\%$ & $0.97 \pm 0.23^{3}$ & $10.4 \pm 1.1^{2}$ \\
$\mathrm{Cervix}$ & $28.5 \pm 2.3$ & $27.2 \pm 2.6$ \\
$\mathrm{ml} / \mathrm{min}$ & & \\
$\mathrm{ml} / \mathrm{min} / \mathrm{g}$ & $4.5 \pm 1.1$ & $53.6 \pm 10.4^{2}$ \\
\hline
\end{tabular}

1 Results are reported as the mean \pm SEM.

${ }^{2}$ Significantly higher than the control value $(P<0.005$, paired $t$ test).

${ }^{3}$ Approximation : calculated by using the uterine weight measured after estrogen stimulation. This stimulation causes an ${ }_{i}$ ncrease of uterine weight due to imbibition of water.

mately $2 \mathrm{hr}$ after estradiol was $283 \pm 50 \mathrm{ml} / \mathrm{min}$. This increase is significant $(P<0.001)$.

The effect of estradiol-17, $\beta$ on the blood flow to the major tissues of the uterus is summarized in Table III. This table shows that the blood flow to all uterine tissues rose markedly after the injection of estrogen.

Since the increase of blood flow relative to the control value was about the same in all the uterine tissues (approximately 10 -fold) there was no significant change of distribution of blood flow within the uterus. Of interest is the fact that under estrogen stimulation the blood flow per gram of tissue in the caruncles was extremely high $(10.4 \mathrm{ml} / \mathrm{min} / \mathrm{g})$.

Vaginal flow increased markedly after estradiol, from $0.2 \pm 0.04$ to $2.5 \pm 0.7 \mathrm{ml} / \mathrm{min} / \mathrm{g}$ tissue $(P=$ $0.01)$.

When the sheep are divided into the previously described "stressed" and "unstressed" groups, there is an obvious difference in the maximum response of the uterine blood flow to estradiol, as illustrated in Fig. 5 . Under estradiol stimulation the flow in the stressed ewes went from $14 \pm 4$ to $161.1 \pm 20 \mathrm{ml} / \mathrm{min}$, whereas that for the unstressed groups of ewes rose from $24 \pm 3$ to $347 \pm 20 \mathrm{ml} / \mathrm{min}$. This difference is significant at $P$ $=0.05$. The arterial pressures in the two groups were also significantly different $(129.9 \mathrm{~mm} \mathrm{Hg} \pm 7.0$ for stressed versus $101.1 \mathrm{~mm} \mathrm{Hg} \pm 3.5$ for unstressed).

Neither the cervical nor vaginal responses to estra- diol stimulation were found to be affected significantly by stress $(P>0.10)$.

The response of mammary blood flow to estradiol is presented in Fig. 6. The mean percentage of increase in mammary blood flow for the stressed animals was

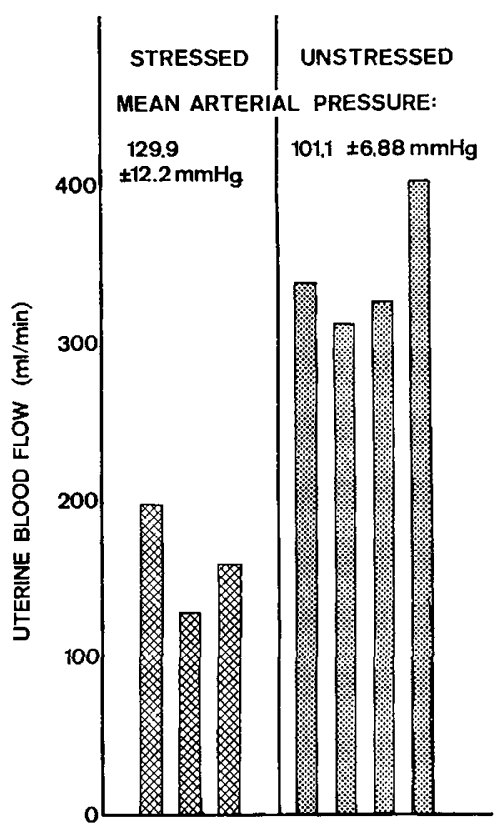

Fig. 5. Comparison of the absolute changes (milliliters per minute) in uterine blood flow measured by the microsphere technique following estradiol- $17, \beta(1 \mu \mathrm{g} / \mathrm{kg})$ in stressed and unstressed nonpregnant ewes. The mean arterial pressure \pm 1 SD is noted.

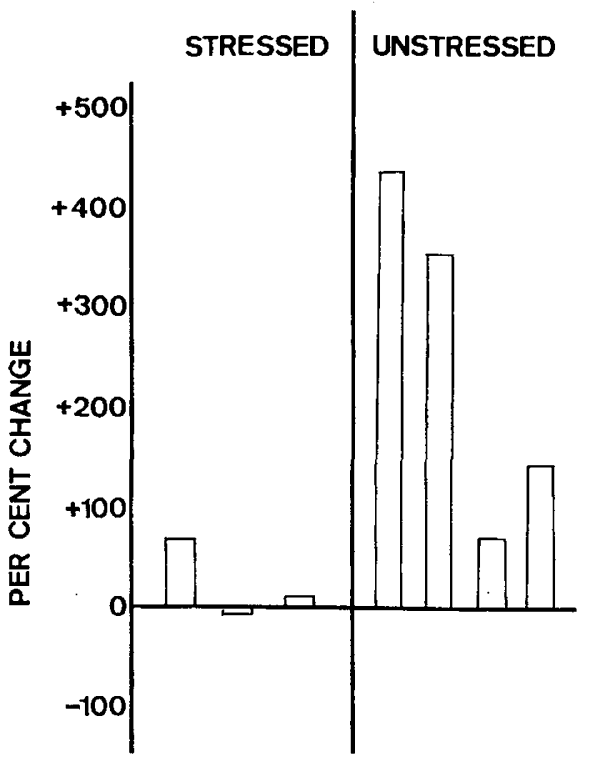

Fig. 6. Comparison of the percentage of change in mammary blood flow after estradiol administration in stressed and unstressed nonpregnant ewes. 
$26.3 \%$, whereas that in the unstressed group was $249.8 \%$. The latter change is significant at $P<0.025$.

The blood flow to other organs and tissues was also measured (heart, kidneys, adrenals, liver, spleen, brain, skin, and skeletal muscle). None of these tissues showed blood flow changes comparable to those observed in the reproductive tissues. Whether estrogens produce relatively small but significant changes of flow to nonreproductive organs is a question that needs further investigation in a larger number of animals. There was no significant change of blood pressure or hematocrit after estrogen stimulation.

\section{Discussion}

The role of estrogens in the physiologic control of the uterine circulation has long been an area of interest in reproductive physiology. Markee [11, 12] used microscopic observations on intraocular transplants of uterine mucosa to demonstrate that estrogens cause a marked dilation of the endometrial vessels. Subsequently, it has been demonstrated that the injection of estrogens causes a significant increase of uterine blood flow in oophorectomized, nonpregnant ewes $[3,6,7]$. The purpose of this investigation was to answer two important questions posed by this knowledge.

The first question concerns the magnitude of the change in uterine blood flow induced by acute estrogen stimulation. Measurements by different techniques and in different laboratories have given variable results. Huckabee et al. [6] observed in chronic, unstressed sheep preparations that the intravenous injection of large doses of estrone caused the uterine blood flow to rise severalfold above control values up to levels that could not be measured with adequate precision by the diffusion-equilibrium method used in that study. An attempt by the same group of investigators to verify this result in anesthetized ewes by means of the direct method of collecting uterine venous blood in a graduated cylinder showed a much smaller uterine flow response to estrogens [6]. Greiss and Anderson [3] used chronic sheep preparations with an electromagnetic flowmeter implanted around the left uterine artery to show that the intramuscular injection of 2 $\mu \mathrm{g} / \mathrm{kg}$ estradiol in oil increased uterine blood flow, but only to a maximum of $24 \mathrm{ml} / \mathrm{min}$. In contrast, we have recently shown [7] by means of electromagnetic flowmeters placed chronically on both uterine arteries, that unanesthetized, unstressed ewes have a marked response in uterine blood flow after the intravenous injection of $1 \mu \mathrm{g}$ estradiol- $17, \beta$, increasing from a con- trol value of $45 \pm 5 \mathrm{ml} / \mathrm{min}$ to a maximum flow, approximately $2 \mathrm{hr}$ after the injection, of $375 \pm 24$ $\mathrm{ml} / \mathrm{min}$. In addition, we have observed that the response is dose dependent and that the stress associated with a relatively mild surgical procedure severely blunts the magnitude of the response. It would seem, then, that the discrepancy of results in the literature could be explained, at least in part, by variability in the physiologic state of the preparation and by variability in the dose and route of administration. Nevertheless, the uterine flow response to acute estrogen stimulation observed by us in the unstressed animal was astonishingly high and it seemed desirable to verify this phenomenon by an independent method. The microsphere technique was selected for this purpose because it is based on a completely different principle than the flowmeter technique, can be used in a chronic, unstressed preparation, and measures flows to exactly defined anatomical areas. The results of the present investigation show good agreement between flow measurements by the two methods performed simultaneously in the same animal (Fig. 4). Furthermore, this study confirms our previous data in two respects: (1) the magnitude of the estrogen-stimulated uterine flow in the unstressed animal $(375 \pm 24 \mathrm{ml} /$ min in 20 studies with the flowmeter method and 347 $\pm 20 \mathrm{ml} / \mathrm{min}$ in 4 microsphere measurements) and (2) the effect of stress in blunting the uterine blood flow response to estrogens. Thus, physiologic doses of estrogens are capable of producing a marked vasodilation of the uterine vessels. In fact, no other hormone or drug has shown an effect comparable in magnitude and duration to the effect of estrogens upon uterine blood flow.

A second, important question concerns the implications of this phenomenon in the physiology of pregnancy. The results of the present investigation provide a partial answer. Estrogen stimulation of the nonpregnant uterus increases proportionally the blood flow to all uterine structures (myometrium, endometrium, and caruncles). This result is in contrast to the observation that in pregnancy the rise of uterine blood flow is primarily due to an increase in placental blood flow [9]. Hence, the $350 \mathrm{ml} / \mathrm{min}$ uterine flow observed in the nonpregnant animal after acute and maximal estrogen stimulation is not comparable, physiologically, with the uterine blood flow of the same magnitude that one observes at midpregnancy in sheep. This comparison indicates that the rise of uterine blood flow in early pregnancy is not related in any simple and direct way to the concentration of estrogens in the systemic 
circulation. On the other hand, the blood flow to the uterine caruncles increases enormously under estrogen stimulation (it increases to values comparable with the blood flow of the carotid body, which is considered the maximum flow per gram of tissue in the organism). The arterioles supplying blood to the caruncles of the nonpregnant uterus are the same arterioles that in pregnancy supply blood to the placental cotyledons. Clearly, then, placental vessels have the potentiality of vasodilating in response to estrogens. Whether this potentiality is masked or maintained in the pregnant state remains to be determined.

There was an increase in blood flow to the other reproductive organs, i.e., mammary glands and vagina, after the infusion of estradiol-17, $\beta$. To the best of our knowledge this is the first report of direct measurements of blood flow to these tissues before and after estrogen stimulation. A recent report by Abrams et al. [1] employing temperature changes in the vaginal mucosa as in index of changes in vaginal blood flow, sug. gests that the vasculature of this tissue responds to estrogens by vasodilation. Blood flow to the mammary gland has been determined previously in goats by the diffusion equilibrium method and by thermodilution $[8,13]$. It would appear that the effect of estrogens on mammary blood flow is severely blunted by stress. In fact, if our experiments had been limited to acute preparations, the capability of the mammary vasculature to vasodilate under estrogen stimulation would have gone unnoticed.

\section{Summary}

The response of the uterine vascular bed to estradiol$17, \beta$ has been studied using two techniques simultaneously for the measurement of uterine blood flow: electromagnetic flow probes and radionuclide-labeled microspheres. After a systemic, 2-min infusion of $1 \mu \mathrm{g} / \mathrm{kg}$ estradiol-17, $\beta$, the total uterine blood flow in seven nonpregnant, oophorectomized ewes increased from a mean base line flow of $20 \pm 3 \mathrm{ml} / \mathrm{min}$ to a maximum flow of $283 \pm 50 \mathrm{ml} / \mathrm{min}$ approximately $2 \mathrm{hr}$ later. Under estrogen stimulation the blood flow to the vagina and mammary gland rose also. The response to estradiol by both the uterus and mammary gland was inhibited when the animal was under the effect of surgical stress.

With the microsphere technique it was shown that estrogen stimulation leads to a rise in blood flow to the myometrium, endometrium, and caruncles. Since the arterioles that supply blood to the caruncles are the same vessels that perfuse the placental cotyledons in the pregnant animal, these data support the hypothesis that estrogens play an important role in the regulation of placental blood flow.

The data presented demonstrate that the vasculature of all of the tissues of the nonpregnant ovine uterus, endometrium, myometrium, and caruncles is extremely sensitive to the vasodilatory effects of estra$\operatorname{diol}-17, \beta$.

\section{References and Notes}

1. Abrams, R. M., Caton, D., And Bozer, F. W.: Effect of estrogen on vaginal blood flow in ewes. Amer. J. Obstet. Gynecol., 113: 681 (1972).

2. Battaglia, F. C., Meschia, G., Makowski, E. L., and Bowes, W.: The effect of maternal oxygen inhalation upon fetal oxygenation. J. Clin. Invest., 47: 548 (1968).

3. Greiss, F. C., AND ANderson, S. G.: Effect of ovarian hormones on the uterine vascular bed. Amer. J. Obstet. Gynecol. 107: 829 (1970).

4. Greiss, F. C., and Martson, E. L.: The uterine vascular bed: Effect of estrogens during ovine pregnancy. Amer. J. Obstet. Gynecol., 93: 720 (1965).

5. Hoffrband, B. I., and Forsyth, R. R.: Validity studies of the radioactive microsphere method for the study of the distribution of cardiac output, organ blood flow and resistance in the conscious Rhesus monkey. Cardiovasc. Res., 3: 426 (1969).

6. Huckabee, W. E., Crenshaw, C., Curet, L. B., Mann, L., and BARRON, D. H.: The effect of exogenous estrogen on the blood flow and oxygen consumption of the uterus of the nonpregnant ewe. Quart. J. Exp. Physiol. Cog. Med. Sci., 55: 16 (1970).

7. Killam, A. P., Rosenfeld, C. R., Bat'raglia, F. C., Makowski, E. L., ANd Meschia, G.: The effect of estrogens on uterine blood flow. Amer. J. Obstet. Gynecol., in press.

8. LINZELL, J. L.: Measurement of venous flow by continuous thermodilution and its application to measurement of mammary blood flow in the goat. Circ. Res., 18: 745 (1966).

9. Makowskr, E. L., Meschia, G., Droegemueller, W., and Batraglia, F. C.: Distribution of uterine blood flow in the pregnant sheep. Amer. J. Obstet. Gynecol., 101: 409 (1968).

10. Makowski, E. L., Meschia, G., Droegemueller, W., AND Battaglia, F. C.: Measurement of umbilical arterial blood flow to the sheep placenta and fetus in utero. Circ. Res., 23: 623 (1968).

11. Markee, J. E.: Rhythmic vascular uterine changes. Amer. J. Physiol., 100: 32 (1932).

12. MARkeE, J. E.: Menstruation in intraocular endometrial transplants in the Rhesus monkey. Contrib. Embryol., 28: 221 (1940).

13. Rasmussen, F.: The mammary blood flow in the cow as measured by the antipyrine adsorption method. Acta Vet. Scand., 6: 135 (1965).

14. Raye J. R., Killam, A. P., Battaglia, F. C., Makowski, E. L., AND Meschia, G.: Uterine blood flow and $\mathrm{O}_{2}$ consumption following fetal death in sheep. Amer. J. Obstet. Gynecol., 111: 917 (1971). 
15. Formocath, Becton, Dickinson and Company, Rutherford, New Jersey.

16. Micron Instrument Company, Los Angeles, Calif.

17. Minnesota Mining and Manufacturing Company, St. Paul, Minn.

18. Midget Stir Plate, Thermolyne, Sybron Corporation, Dubuque, Iowa.

19. Nuclear-Chicago Corporation, Des Plaines, Ill.
20. This work was supported in part by United States Public Health Service Grants nos. HD 00781 and HD 01866.

21. Requests for reprints should be addressed to: Frederick C. Batraglia, M.D., Division of Perinatal Medicine, Container 2302 and 4200 East Ninth Avenue, University of Colorado Medical Center, Denver, Colo. 80220 (USA).

22. Accepted for publication November 27, 1972. 